\title{
New Reforms to the Health System
}

Candice Tran Dai and Mathieu Duchâtel

\section{(2) OpenEdition}

\section{Journals}

\section{Electronic version}

URL: http://journals.openedition.org/chinaperspectives/4861

DOI: 10.4000/chinaperspectives.4861

ISSN: 1996-4617

\section{Publisher}

Centre d'étude français sur la Chine contemporaine

\section{Printed version}

Date of publication: 1 September 2009

ISSN: 2070-3449

\section{Electronic reference}

Candice Tran Dai and Mathieu Duchâtel, « New Reforms to the Health System », China Perspectives [Online], 2009/3 | 2009, Online since 01 September 2012, connection on 15 September 2020. URL : http://journals.openedition.org/chinaperspectives/4861

This text was automatically generated on 15 September 2020

(c) All rights reserved 


\title{
New Reforms to the Health System
}

\author{
Candice Tran Dai and Mathieu Duchâtel
}

\section{ABSTRACTS}

Based on:

- Li Ling, "Successful reform of the health system hangs on two key elements," Zhongguo jingyingbao (China Management News), 18 April 2009.

- Li Hongmei, Li Xiaohong, Wang Junping, "Ten experts comment on the new reform of the health system: Providing better and cheaper access to medical care," Renmin ribao (People's Daily), 15 April 2009.

- Yao Qi, "The new reform of the health system must first and foremost compensate for the shortcomings in the local hospitals," Yangcheng wanbao (Yangcheng Evening News), 8 April 2009.

- Gu Xin, "The freeing-up of doctors: A major step forward in the administrative makeover of medical services," Liaowang dongfang zhoukan (Oriental Outlook), 29 April 2009 